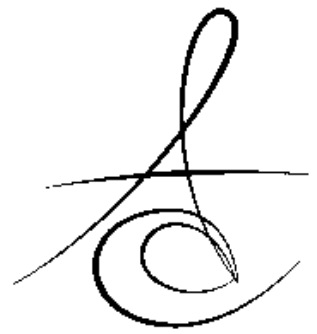

\title{
AN INVESTIGATION OF RELATIONSHIP BETWEEN TONSILLOLITH AND CAROTID ARTERY CALCIFICATION ON PANORAMIC RADIOGRAPHY
}

\section{PANORAMİK RADYOGRAFİDE TONSİL TAŞI VE KAROTİS ARTER KALSİFİKASYONU ARASİNDA Kİ İLIŞKİNİN İNCELENMESİ}

\author{
Doç. Dr. Binali ÇAKUR* \\ Arş. Gör. Eren YILDIRIM*
}

Arş. Gör. Ömer DEMİRTAŞ*

\author{
Makale Kodu/Article code: 1174 \\ Makale Gönderilme tarihi; 17.05 .2013 \\ Kabul Tarihi: 22.10 .2013
}

\section{ABSTRACT}

Aim: Carotid artery calcification can results in important vascular obstruction. It is reported that the combination of risk factors such as periodontitis, pulp stones contribute to carotid artery calcification. However in the literature, no study has yet investigated carotid artery calcification with respect to tonsillolith. The objective of this study was to investigate whether carotid artery calcification correlate with tonsillolith using dental panoramic radiography.

Material and method: Panoramic radiographs were examined to detect carotid artery calcification and tonsillolith.

Results: There was no correlation between the carotid artery calcification and tonsillolith.

Conclusion: It can be stated that there is no relationship between carotid artery calcification and tonsillolith.

Key words: Carotid artery, panoramic radiography, calcification, tonsillolith

\section{ÖZET}

Amaç: Karotis arter kalsifikasyonu önemli damar tıkanıkları ile sonuçlanabilir. Periodontitis, pulpa taşları gibi risk faktörlerinin karotis arter kalsifikasyonunda etkili olduğu bildirilmiştir. Ancak literatürde, tonsil taşı ve karotis arter kalsifikasyonu ilişkisiyle ilgili herhangi bir çalışma yoktur. Bu çalışmanın amacı, panoramik radyografide karotid arter kalsifikasyonun tonsil taşı ile ilişkili olup olmadığını araştırmaktır.

Gereç ve yöntem: Panoramik radyografiler karotis arter kalsifikasyonu ve tonsil taşı varlığı açısından kontrol edildi.

Bulgular: Karotis arter kalsifikasyonu ve tonsillolith arasında bir ilişki yoktu.

Sonuç: Karotis arter kalsifikasyonu ve tonsillolith arasında bir ilişki olmadığı söylenebilir.

Anahtar kelimeler: Karotis arter, panoramik radyografi, kalsifikasyon, tonsil taşı

\section{INTRODUCTION}

Atherosclerosis is caused by an abnormal accumulation of lipids on the walls of the arteries. The carotid bifurcation region is at the highest risk of atherosclerosis because of increased turbulent flow, flow velocity and shear stress. ${ }^{1,2}$ Carotid artery calcification (CAC) can results in important vascular obstruction causing stroke. On the other hand, carotid atherosclerotic disease is one of the major preventable causes of ischemic strokes. ${ }^{3}$ For this reason,especially in asymptomatic patients with carotid atherosclerosis, early detection of this disease reduces the morbidity and mortality. ${ }^{4}$ The presence of CAC can be detected by either non-invasive techniques, such as Doppler ultrasound or invasive techniques, such as digital subtraction angiography. ${ }^{3}$ However, in dentistry, carotid artery calcifications can be detected by the panoramic radiography. ${ }^{4-6}$ Calcifications within the carotid artery are located in the soft tissue below the

*Atatürk Üniversitesi, Diş Hekimliği Fakültesi, Ağız, Diş ve Çene Radyolojisi Anabilim Dalı Erzurum 
angle of the mandible and between the hyoid bone and the image of the cervical spine as seen in panoramic images. ${ }^{7}$ Tonsillolith is a rare dystrophic calcification. ${ }^{8}$ Tonsillolith is composed primarily of calcium and other minerals such as phosphorus, ammonia, carbonate and magnesium. ${ }^{9-11}$ The exact etiology and pathogenesis is unknown, ${ }^{7}$ although they appear to result from the accumulation of material retained within the crypts, along with the growth of bacteria and fungi. ${ }^{12,13}$ The absence of clinical signs and symptoms is probably due to the small size of the calcifications; thus, the lesions were incidentally detected during panoramic radiographic examination. ${ }^{7}$

It is reported that the combination of risk factors such as periodontitis, pulp stones contribute to CAC. However, in the literature no study has yet investigated about the relationship between tonsillolith and CAC. Therefore, the present study was performed with the aim of investigating whether carotid artery calcification correlate with tonsillolith using dental panoramic radiography.

\section{MATERIAL AND METHODS}

We designed a retrospective study consisting of the images of 847 the patients (293 male, 554 female aged 20 to 79 years; mean age, 37.7 years) who presented to our clinic between June 2011 and February 2012. Panoramic radiographs of all patients were taken when the patients were seen for routine dental care. All images were exposed to 60-80 kV and 1-10 mA from a digital X-ray unit (Morita, MFG Corp., Kyoto, Japan) for $12 \mathrm{~s}$ with three rotation centers and a constant magnification of $\times 1.3$. Panoramic radiographs were obtained in full compliance to the reference points specified by the manufacturer on the device. Panoramic radiographs were evaluated for the presence or absence of both CAC and tonsillolith on both the right and left sides of the mandibular angle. Selection criteria for panoramic radiographs included correct patient positioning (anterior teeth not showing excessive horizontal or vertical magnification, equal ramus width bilaterally, no superimposition of the cervical spine over the ramus). Panoramic radiographs were examined to detect carotid artery calcifications appearing as heterogeneous radiopacities in a verticolinear orientation adjacent to the hyoid bone, epiglottis and the cervical vertebrae either above or below the intervertebral space between C3 and C4 (Fig. 1). For the differential diagnosis of CACs, other cervical calcifications were excluded according to Carter's study. ${ }^{14}$ Carter et al. $^{14}$ reported that calcifications at the carotid bifurcation have a distinct radiographic appearance and location that distinguishes CAC from other radiopacities in the same region (including those seen on the hyoid bone, epiglottis, ear lobe, styloid process, and calcified stylohyoid ligament). On the panoramic radiograph, the most common appearance of tonsilloliths is a cluster of multiple, small, ill-defined radiopacities slightly more radiopaque than cancellous bone, similar to cortical bone. A cluster of multiple, small, ill-defined radiopaque mass adjacent to the bone at or below the mandibular angle were diagnosed as tonsillolith ${ }^{10,12}$ (Fig. 2). Images were viewed in a darkened room on 2 computers with 17-inch LCD monitors with the same screen resolution by two oral and maxillofacial radiologists.

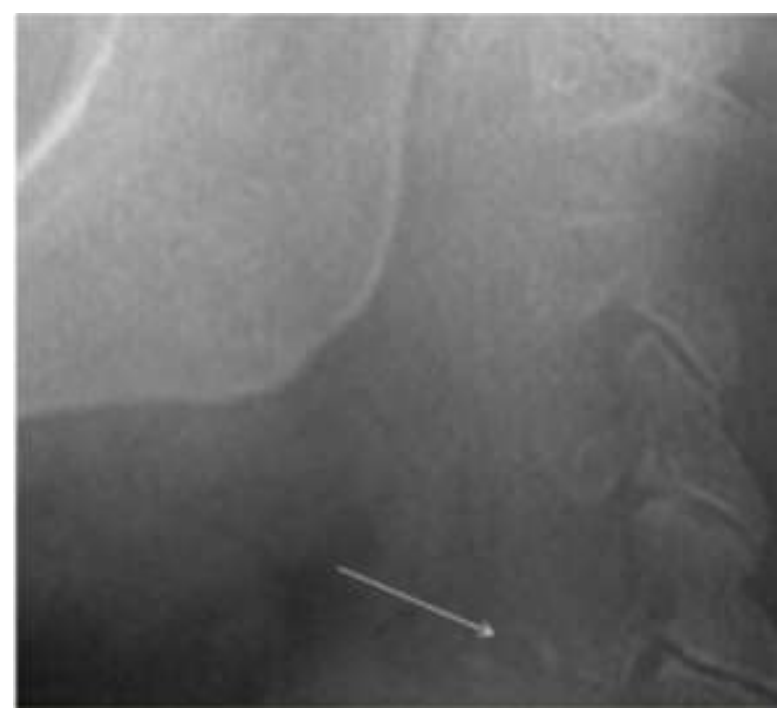

Figure 1. Panoramic radiograph showing radiopacities in the left carotid vasculature area (carotid artery calcification, white arrow). 


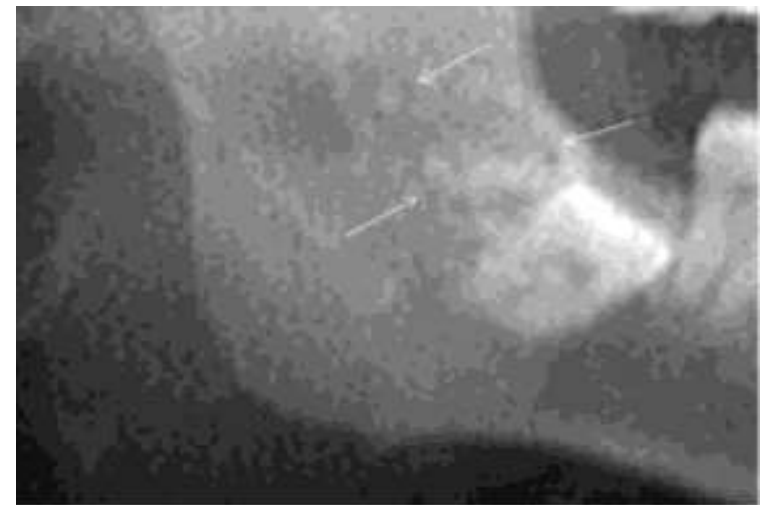

Figure 2. Panoramic radiograph showing radiopaque masses superimposed over the right ascending ramus (tonsillolith, white arrows).

\section{Statistical analyses}

Statistical analyses were calculated using the SPSS $₫$ statistics program (SPSS $®$ v11.5; SPSS Inc., Chicago, Ill., USA). Correlation between the CAC and tonsillolith was established using the Pearson's correlation coefficient with the significance set at $p<$ 0.05 . Students't test was used to compare means of female and male.

\section{RESULTS}

Table 1 shows descriptive statistics of age, carotid artery calcification, and tonsillolith. In this study, there was no a statistically correlation between the CAC and tonsillolith (Table 2). Results of Students't test comparing means of female and male showed that a statistically significant difference was observed only the CAC (Table 3). The CAC was seen more frequently in the male patients. .

\section{DISCUSSION}

In detecting and preventing of carotid atherosclerotic disease, imaging plays a major role. $^{3}$ On panoramic radiography, the CACs may be seen as either single or multiple discrete radiopaque vertical line or nodular radiopaque mass $1.5 \mathrm{~cm}$ inferior and $2.5 \mathrm{~cm}$ posterior to the cortical rim of the midpoint of the mandibular angle and adjacent to the cervical vertebrae at the level of the C3-C4 intervertebral junction. ${ }^{15}$ Normally, bifurcation level of the right carotid artery is more often located between C3 and C4, whereas that of the left carotid artery is located between $\mathrm{C} 4$ and $\mathrm{C} 5 .{ }^{16}$ Sisman et al. ${ }^{1}$ retrospectively investigated the prevalence of CACs on 750 PRs in a Turkish population. They found that the CACs were not significantly different between the males and females. But Tamura et al. ${ }^{17}$ and Bayram et al. ${ }^{18}$ revealed that the incidence of the CAC was higher in female patients. Contrary to other studies, ${ }^{1,17,18}$ we found that the incidence of the CAC was higher in male patients. In the literature no study has yet investigated carotid artery calcification with respect to tonsillolith. In this study, there was no correlation between the carotid artery calcification and tonsillolith. To our knowledge, this is the first study so it has not been possible to undertake a meta-analysis. However, it is reported that the combination of risk factors such as hyperlipidemia, hypertension, renal disease, diabetes mellitus, obstructive sleep apnea syndrome, periodontitis, pulp stones, ethnicity, dietary factors, lifestyle, and regional differences contribute to CACs. ${ }^{17}$ The exact etiology and pathogenesis of the tonsillolith is unknown. ${ }^{9,10-13,19}$ The association of tonsillolith with kidney stone, gall stones, and Wharton's duct stones suggests that tonsillolith could be a part of the lithogenic diathesis. ${ }^{9,20-22}$ On a panoramic radiograph, tonsilloliths appear as single or multiple radiopacities that overlap the midportion of the mandibular ramus in the region where the dorsal surface of the tongue crosses the ramus in the palatoglossal or glossopharyngeal air spaces. The most common appearance of tonsilloliths is a cluster of multiple, small, ill-defined radiopacities slightly more radiopaque than cancellous bone, similar to cortical bone. ${ }^{23-26}$ Pruet and Duplan ${ }^{27}$ reported an equal sex distribution of tonsillolith. But, Ram et al. ${ }^{10}$ reported that tonsilloliths occur twice as commonly in males than in females. In our study, no difference was observed between genders with respect to tonsillolith. The discrepancy between the frequency of CAC and tonsillolith in our study and that in other studies. ${ }^{1,10,17,18,27}$ may be due to the number of patients examined, the patient sample, and the difference in the examining techniques and equipment.

This study has some limitations. One problem or limitation was that all patients with dental problems in the study came from the same source. Another factor to note is the lack of medical history for our sample. Only the age, sex, dates of panoramic

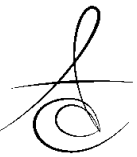


radiography were known for the patient. One of the other drawbacks of our study was that it included almost one half times (293 males to 554 females) the number of female subjects when compared to the males. In addition, CACs and tonsillolith may be difficult to diagnose because they may be mistaken for other anatomic and pathologic structures of the cervical region, especially on routine panoramic radiographs. When the soft tissue calcification is adjacent to bone, it is sometimes difficult to determine whether the calcification is within bone or soft tissue.

In conclusion, it can be stated that there is no relationship between carotid artery calcification and tonsillolith. In addition, carotid artery calcification is seen more frequently in the male patients. However, future well-designed studies involving larger numbers of subjects will be necessary to confirm the finding of this study and to understand more about the relationship between tonsillolith and CAC.

\section{Conflict of interest}

The authors declared no conflicts of interest.

\section{REFERENCES}

1. Sisman Y, Ertas ET, Gokce C, Menku A, Ulker M, Akgunlu F. The Prevalence of carotid artery calcification on the panoramic radiographs in cappadocia region population. Eur J Dent 2007; 1:132-8.

2. Yoon SJ, Yoon W, Kim OS, Lee JS, Kang BC. Diagnostic accuracy of panoramic radiography in the detection of calcified carotid artery. Dentomaxillofac Radiol 2008; 37:104-8.

3. U-King-Im JM, Young V, Gillard JH. Carotid-artery imaging in the diagnosis and management of patients at risk of stroke. Lancet Neurol 2009; 8:569-80.

4. Ertas ET, Mavili E, Sisman Y, Sahman H, Etoz M, Sekerci AE. Incidental findings of carotid artery stenosis detected by calcifications on panoramic radiographs: report of three cases. Oral Radiol 2010; 26:116-21.

5. Çakur B, Sümbüllü MA, Yılmaz AB. Dental volumetric tomography in the radiological detection of carotid artery calcification. Anadolu Kardiyol Der 2011; 11: 652-4.
6. Scarfe WC, Farman AG. Soft tissue calcifications in the neck: maxillofacial CBCT presentation and significance. AADMRT Currents 2010; 2:1-15.

7. Moura MDG, Madureira DF, Noman-Ferreira LC, Abdo EN, Aguiar EG, Freire ARS. Tonsillolith: A report of three clinical cases. Med Oral Patol Oral Cir Bucal 2007; 12:e130-3.

8. Neville BW, Damm DD, Allen CM, Bouquot JE. Oral and Maxillofacial Pathology. 2nd ed. Philadelphia: W.B. Saunders, 2002;166.

9. Cooper MM, Steinberg JJ, Lastra M, Antopol S. Tonsillar calculi. Report of a case and review of the literature. Oral Surg Oral Med Oral Pathol 1983; 55:239-43.

10. Ram S, Siar $\mathrm{CH}$, Ismail SM, Prepageran N. Pseudo bilateral tonsilolliths. A case report and a review of literature. Oral Surg Oral Med Oral Pathol Oral Radiol Endod 2004; 98:110-4.

11. Hadi UM, Samara MS. Giant tonsillolith. Ear Nose Throat J 1985; 64:507-8.

12. Mody RN, Srivastava S. Bilateral multiple tonsilloliths. Oral Radiol 2009; 25:67-70.

13. Silvestre-Donat FJ, Pla-Mocholi A, Estelles-Ferriol E, Martinez-Mihi V. Giant tonsillolith: report of a case. Med Oral Pathol Oral Cir Buccal 2005; 10:239-42.

14. Carter LC. Discrimination between calcified triticeous cartilage and calcified carotid atheroma on panoramic radiography. Oral Surg Oral Med Oral Pathol Oral Radiol Endod 2000; 90:108-10.

15. Friedlander $\mathrm{AH}$, Maeder LA. The prevalence of calcified carotid artery atheromas on the panoramic radiographs of patients with type 2 diabetes mellitus. Oral Surg Oral Med Oral Pathol Oral Radiol Endod 2000; 89:420-4.

16. Mehdizadeh M, Naghavi E. Evaluation of calcified carotid artery atheromas detected by panoramic radiograph above 50-years-old in Isfahan. Pak Oral Dent J 2008; 28:249-52.

17. Tamura $T$, Inui $M$, Nakase $M$, Nakamura $S$, Okumura K, Tagawa T. Clinico statistical study of carotid calcification on panoramic radiographs. Oral Diseases 2005; 11:314-7.

18. Bayram B, Uckan S, Acikgoz A, Muderrisoglu H, Aydinalp A. Digital panoramic radiography: a reliable method to diagnose carotid artery atheromas? Dentomaxillofac Radiol 2006; 35: 266-70. 
19. Hiranandani LH. A giant tonsillolith. J Laryngol Otol 1967; 81:819-22.

20. Neshat K, Penna KJ, Shah DH: Tonsillolith. a case report. J Oral Mixillofac Surg 2001; 59:692-3.

21. Swain HI. Recurrent Calculus of the TonsilReport of a case. Ann Otol Rhinol Laryngol 1920; 29:73-8.

22. Jones WJ. A tonsillolith. BDJ 1996; 180:128.

23. Carter LC. Soft tissue calcification and ossification. In: White SC, Pharoah ML, eds. Oral radiology: principles and interpretation. St. Louis: Mosby, 2004; 598-606.

24. White SC, Pharoah MJ. Oral Radiology:principles and interpretation. 4th ed. St. Louis: Mosby, 2000; 554-6.

25. Mesolella M, Cimmino M, Di Martino M, Criscuoli G, Albanese L, Galli V. Tonsillolith. Case report and review of the literature. Acta Otorhinolaryngol Ital 2004; 24:302-7.

26. Westmore B, Hupp J. Tonsillolith. Oral Surg Oral Med Oral Pathol 1988; 65:783.

27. Pruet CW, Duplan DA. Tonsil concretions and tonsilloliths. Otolaryngol Clin North Am 1987; 20:305-9.

\section{Yazışma Adresi:}

Doç. Dr. Binali ÇAKUR

Atatürk Üniversitesi

Diş Hekimliği Fakültesi

Oral Diagnoz ve Radyoloji Anabilim Dalı 25240 Erzurum / TÜRKIYYE

Telf.: +90.442.231 1765

FaksI: +90.442.2360945

E-mail: bcakur@atauni.edu.tr 